\title{
REVIEW
}

\section{Clinical relevance and biology of circulating tumor cells}

Natalia Bednarz-Knoll', Catherine Alix-Panabières ${ }^{2,3,4}$ and Klaus Pantel|**

\begin{abstract}
Most breast cancer patients die due to metastases, and the early onset of this multistep process is usually missed by current tumor staging modalities. Therefore, ultrasensitive techniques have been developed to enable the enrichment, detection, isolation and characterization of disseminated tumor cells in bone marrow and circulating tumor cells in the peripheral blood of cancer patients. There is increasing evidence that the presence of these cells is associated with an unfavorable prognosis related to metastatic progression in the bone and other organs. This review focuses on investigations regarding the biology and clinical relevance of circulating tumor cells in breast cancer.
\end{abstract}

\section{Introduction}

Detection of circulating tumor cells (CTCs) in peripheral blood and disseminated tumor cells (DTCs) in bone marrow of tumor patients has become an active area of translational cancer research, with numerous groups developing new diagnostic assays and more than 200 clinical trials incorporating CTC counts as a biomarker in patients with various types of solid tumors. Among these activities, breast cancer has played the most prominent role as a 'driver' of research on CTCs/DTCs. The clinical relevance of DTCs is already well-established $[1,2]$ and has been confirmed by different large-scale studies, including a pooled analysis on almost 5,000 patients [3]. Aspirations of bone marrow, a common homing organ for many types of solid tumors [1,4], are part of the routine screening of leukemia patients and are much less difficult to perform than biopsies of other organs (for example, lungs or liver). Nevertheless, it is

*Correspondence: pantel@uke.uni-hamburg.de

'Department of Tumour Biology, University Medical Centre Hamburg-Eppendorf,

Martinistr. 52, 20246 Hamburg, Germany

Full list of author information is available at the end of the article still a painful and invasive procedure that is not comfortable for patients and, due to this fact, has not yet been accepted for routine diagnosis of solid tumors. In contrast, CTCs are easier to obtain by peripheral blood sampling, which can be repeated frequently, allowing real-time monitoring of metastatic progression. Thus, it seems that peripheral blood might serve as a perfect alternative source of material to diagnose cancer patients, and CTC analysis in cancer patients has thus been termed a 'liquid biopsy' [5].

On the other hand, detection of CTCs is hampered by the still uncertain biology of these cells, which most likely inherit a heterogeneous malignant potential to home and give rise to overt metastasis in secondary organs. Even modern technologies that have been applied to isolate and characterize CTCs still need to be improved [6]. Although recent results on significant associations between the presence of CTCs and subsequent occurrence or progression of metastases are encouraging, the clinical relevance and utility of CTCs merit further investigation and confirmation by multicenter trials.

Developments in CTC/DTC technologies over the past few years have been impressive. This review will recapitulate the current knowledge on CTCs in breast cancer patients with a focus on the biology and clinical relevance of these cells.

\section{Tumor cell dissemination: a complex process}

During tumorigenesis subsets of tumor cells localized within the primary tumor might acquire features of invasiveness and motility and enter blood or lymph vessels (Figure 1). Mechanisms involved in this process are still under investigation; however, they are already reported to be linked to variable interactions between tumor cells and the surrounding stroma, including, for example, response to hypoxia and metalloproteinasedependent invasion into surrounding tissue, (neo-)vascularization of a tumor [7], as well as gain of a phenotype revealing signatures of epithelial-mesenchymal transition (EMT) observed in at least a subpopulation of tumor cells with certain 'stemness' properties [8-10].

Once cells spread and survive, they might establish a separate secondary tumor site in a new environment of a 


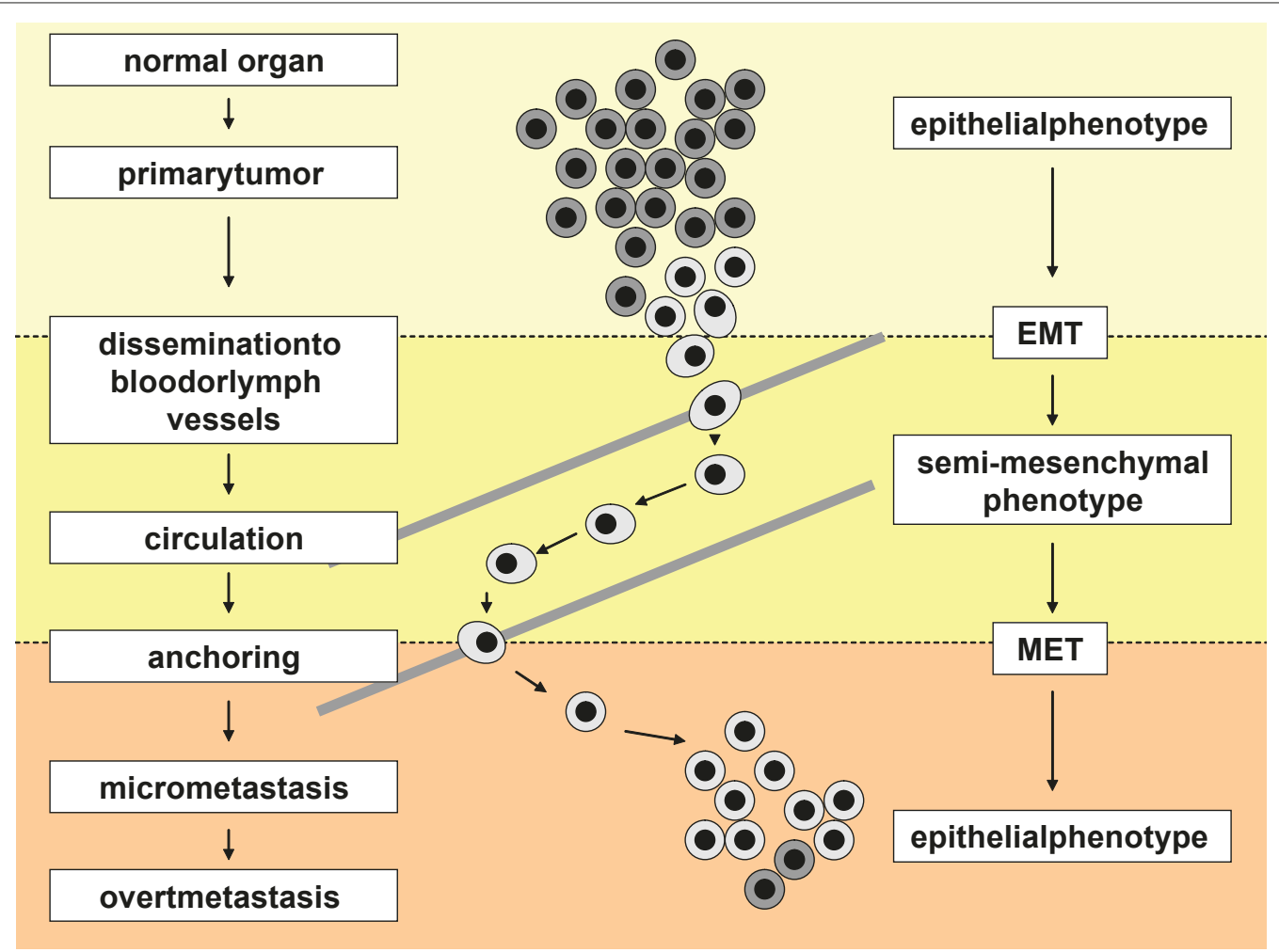

Figure 1. Phenotypic changes of breast cancer cells during dissemination and metastasis. Epithelial tumor cells that originated from a primary tumor might transform into more aggressive phenotypes and disseminate into the blood or lymph circulation. Due to this altered phenotype, which is frequently associated with epithelial-mesenchymal transition (EMT), their detection and identification in blood of cancer patients is significantly hampered. After surviving in the blood stream and homing to a secondary organ, tumor cells may undergo mesenchymalepithelial transition (MET) and assimilate into the new environment of their secondary site (for example, bone marrow). This process will lead to the establishment of occult micrometastases that may eventually grow out to overt metastases detectable with current imaging methods.

host organ (for example, bone marrow, liver, lung or brain). CTCs/DTCs, however, can also undergo apoptosis or persist in an inactive, so-called dormant state for years [11]. CTCs that extravasate need to survive as DTCs in their new microenvironment, which might be supported by finding and/or establishing a proper niche. These DTCs might transform into more aggressive variants and grow out to overt metastasis [7] and/or they may recirculate to other secondary organs or even back to their primary tumor site $[12,13]$.

Dissemination might appear in a late phase of tumorigenesis when a primary tumor achieves a critical mass of cells and gains a highly aggressive phenotype (linear model) or it might be initiated much earlier, even when a malignant tumor is still of small size (parallel model) [14]. In the linear model subsequent events gradually lead to tumor progression, whereas in the concurrent parallel model CTCs/DTCs settle down in distant organs, creating a clone that evolves in parallel to a primary site. In both models occurrence of metastasis is usually fatal for a patient.

\section{Circulating tumor cell detection}

CTC detection remains a big technical challenge despite the continued development of many new exciting technologies [1]. The key problem is to define a technology that will detect the real metastasis-initiating CTC that will give rise to distant metastases. It is conceivable that this will be a combination of complementary technologies or even several technologies optimized for specific tumor types, including breast cancer. Some of the current key technologies for the enrichment and detection of CTCs are listed in Table 1. As CTCs occur at very low concentrations of one tumor cell in a background of millions of blood cells, enrichment is usually required prior to CTC detection. CTC enrichment involves a large panel of technologies based on the different properties of CTCs that distinguish them from the surrounding normal hematopoietic cells: physical properties (size, density, electric charges, deformability) and/or biological properties (surface protein expression, viability and invasion capacity). It is important to note that most of the current technologies are still based on epithelial cell adhesion 
Table 1. Current technologies for CTC detection

\begin{tabular}{|c|c|c|c|}
\hline Assay system & Enrichment & Detection & Comments \\
\hline \multicolumn{4}{|l|}{ EPCAM-based assays } \\
\hline CellSearch ${ }^{\oplus}$ system & $\begin{array}{l}\text { Immunomagnetic beads: } \\
\text { EpCAM-Ab-coupled } \\
\text { ferrofluid }\end{array}$ & $\begin{array}{l}\text { Immunocytochemistry: } \\
\text { Positive for CK8, } 18,19 \\
\text { Negative for CD } 45 \\
\text { Nucleus positive for DAPI }\end{array}$ & $\begin{array}{l}\text { Semi-automated system with FDA approval for metastatic } \\
\text { breast, colon and prostate cancer. CTC can be enumerated and } \\
\text { visualized [2] }\end{array}$ \\
\hline CTC-chip & $\begin{array}{l}\text { Microposts: EpCAM-Ab- } \\
\text { coupled microposts }\end{array}$ & $\begin{array}{l}\text { Immunocytochemistry: } \\
\text { Positive for CK8, } 18,19 \\
\text { Negative for CD } 45 \\
\text { Nucleus positive for DAPI }\end{array}$ & $\begin{array}{l}\text { High detection rate (approximately } 100 \% \text { ) even in } \mathrm{M}_{0} \text {-patients } \\
\text { warrants further investigations on assay specificity; the } \\
\text { Herringbone second generation of this microchip is more } \\
\text { specific. Needs to be validated in clinical trials [67-70] }\end{array}$ \\
\hline CTC-chip Ephesia & $\begin{array}{l}\text { Column of nanobeads: } \\
\text { EpCAM-Ab-coupled } \\
\text { ferrofluids }\end{array}$ & $\begin{array}{l}\text { Immunocytochemistry: } \\
\text { Positive for CKs } \\
\text { Negative for CD45 } \\
\text { Nucleus positive for DAPI }\end{array}$ & Lack of validation studies in clinical settings [71] \\
\hline MagSweeper & $\begin{array}{l}\text { Immunomagnetic beads: } \\
\text { EpCAM-Ab-coupled } \\
\text { ferrofluids }\end{array}$ & $\begin{array}{l}\text { Microscope visualisation: } \\
\text { Morphology }\end{array}$ & $\begin{array}{l}\text { Isolation of CepC with a high degree of purity. Analysis of large } \\
\text { blood volume [72] }\end{array}$ \\
\hline $\begin{array}{l}\text { Laser scanning } \\
\text { cytometry Maintrac }\end{array}$ & RBC lysis & $\begin{array}{l}\text { Immunocytochemistry: } \\
\text { Positive for EpCAM } \\
\text { Negative for CD45 }\end{array}$ & $\begin{array}{l}\text { High incidence of positive events up to } 3 \text { logs higher CTC } \\
\text { counts than those obtained with other techniques warrants } \\
\text { further investigations of assay specificity [73] }\end{array}$ \\
\hline $\begin{array}{l}\text { Ikoniscope }{ }^{\circledast} \text { imaging } \\
\text { system }\end{array}$ & $\begin{array}{l}\text { Ficoll-Isopaque or } \\
\text { filtration with track-etched } \\
\text { membranes }\end{array}$ & $\begin{array}{l}\text { Immunocytochemistry: } \\
\text { Positive for EpCAM, CK7/8 } \\
\text { PSA (prostate only) } \\
\text { FISH: chromosomes } 7 \text { and } 8 \\
\text { Nucleus positive for DAPI }\end{array}$ & $\begin{array}{l}\text { Two epithelial specific Abs and FISH to detect chromosomal } \\
\text { abnormalities in CTCs [74] }\end{array}$ \\
\hline Ariol ${ }^{\oplus}$ system & $\begin{array}{l}\text { RBC lysis, then } \\
\text { immunomagnetic beads: } \\
\text { CK-Ab- + EpCAM-Ab- } \\
\text { coupled ferrofluids }\end{array}$ & $\begin{array}{l}\text { Immunocytochemistry: } \\
\text { Positive for CK8, } 18,19 \\
\text { Negative for CD } 45 \\
\text { Nucleus positive for DAPI }\end{array}$ & Detection of EpCAM+ and EpCAM- CTCs [75] \\
\hline AdnaTest & $\begin{array}{l}\text { Immunomagnetic beads: } \\
\text { MUC1-, EpCAM-Ab-coupled } \\
\text { microbeads }\end{array}$ & $\begin{array}{l}\text { Molecular biology: RT-PCR } \\
\text { Positive for at least one of the following } \\
\text { markers: MUC1, HER2, EpCAM }\end{array}$ & $\begin{array}{l}\text { AdnaTest also does not quantify the tumour cell load, false } \\
\text { positive results due to unspecific amplification, no further } \\
\text { analysis possible [76] }\end{array}$ \\
\hline \multicolumn{4}{|l|}{ Functional assays } \\
\hline EPISPOT assay & $\begin{array}{l}\text { Rosette plus Ficoll: } \\
\text { Depletion of CD } 45^{+} \text {cells }\end{array}$ & $\begin{array}{l}\text { Secretion of proteins: } \\
\text { CK19, MUC1, Cath-D (breast); CK19 } \\
\text { (colon); PSA (prostate); TG (thyroid) }\end{array}$ & $\begin{array}{l}\text { Detection of viable epithelial secreting-cells; unbiased } \\
\text { enrichment independent of CTC/DTC phenotype }[41,77]\end{array}$ \\
\hline $\begin{array}{l}\text { Vita-Assay' }{ }^{\top \mathrm{M}} \text { or } \\
\text { Collagen Adhesion } \\
\text { Matrix (CAM) } \\
\text { technology }\end{array}$ & $\begin{array}{l}\text { Invasion capacity: } \\
\text { Ingestion of fluorescent } \\
\text { CAM fragments (CAM+) }\end{array}$ & $\begin{array}{l}\text { Immunocytochemistry: } \\
\text { Positive for EpCAM, ESA, pan-CK 4, 5, 6, } \\
8,10,13 \text { and } 18 \\
\text { Negative for CD45 }\end{array}$ & Detection of CTCs with the invasive phenotype in blood [78] \\
\hline \multicolumn{4}{|l|}{ Others } \\
\hline ISET & Cell size & $\begin{array}{l}\text { Immunocytochemistry: } \\
\text { Positive for CK } \\
\text { Nucleus: Mayer's hematoxylin }\end{array}$ & $\begin{array}{l}\text { Sensitivity threshold of one carcinoma cell per milliliter of } \\
\text { blood; HER2 amplification determined by real-time PCR on DNA } \\
\text { extracted from CK immunostained cells (CTCS) collected by laser } \\
\text { microdissection from selected ISET-positive filters; the possibility } \\
\text { of false-positive diagnosis stresses the need for using ancillary } \\
\text { methods to improve this approach [79-81] }\end{array}$ \\
\hline $\begin{array}{l}\text { FAST (fiber-optic } \\
\text { array scanning } \\
\text { technology) }\end{array}$ & No pre-enrichment & $\begin{array}{l}\text { Immunofluorescence: } \\
\text { Positive for CK } \\
\text { Nucleus positive for DAPI } \\
\text { Morphology }\end{array}$ & $\begin{array}{l}\text { Rare cells detected by laser scanning to almost } 1,000 \text { times faster } \\
\text { than digital microscopy }[82,83]\end{array}$ \\
\hline $\begin{array}{l}\text { DEP-FFF } \\
\text { (dielectrophoretic } \\
\text { field-flow } \\
\text { fractionation) }\end{array}$ & $\begin{array}{l}\text { Phenotype - membrane } \\
\text { capacitance }\end{array}$ & $\begin{array}{l}\text { Immunocytochemistry: } \\
\text { Wright stain }\end{array}$ & $\begin{array}{l}\text { No need for labeling or modification of CTCS; PBMC/CTC ratio is } \\
\text { enriched more than 2000-fold; CTCs isolated by DEP are viable } \\
\text { and suitable for a wide spectrum of analyses [84] }\end{array}$ \\
\hline $\begin{array}{l}\text { Versatile label free } \\
\text { biochip }\end{array}$ & Cell size deformability & $\begin{array}{l}\text { Immunofluorescence: } \\
\text { Positive for CK } \\
\text { Negative for CD45 } \\
\text { Nucleus positive for DAPI } \\
\text { Morphology }\end{array}$ & $\begin{array}{l}\text { Label free selection and CTCs are viable after blood processing } \\
\text { [85] }\end{array}$ \\
\hline
\end{tabular}

Abbreviations: Ab, antibody; BM, bone marrow; Cath-D, cathepsin D; CepC, circulating epithelial cell; CK, cytokeratin; CTC, circulating tumor cell; DAPI, 4,6-diamidino2-phenylindole; DEP, dielectrophoresis; DTC, disseminated tumor cell; EpCAM, epithelial cell adhesion molecule; EPISPOT, EPIthelial immunoSPOT; ESA, epithelial specific antigen; FDA, Food and Drug Administration; FISH, fluorescent in situ hybridization; ISET, isolation by size of epithelial tumor cells; MUC1, mucine 1; NSCLC, non-small-cell lung cancer; PBMC, peripheral blood mononuclear cells; PSA, prostate specific antigen; RBC, red blood cell; RT-PCR, reverse transcription polymerase chain reaction; TG, thyroglobulin. 
molecule (EpCAM) expression (Table 1). However, due to the assumption that EMT may occur particularly during tumor cell dissemination and this might be accompanied by EpCAM downregulation, new emerging technologies also try to capture EpCAM-negative CTCs (Table 1).

As outlined in more detail below, an ideal CTC detection method might include epithelial markers not repressed during EMT and/or mesenchymal markers induced during EMT. Moreover, it is important to distinguish viable from apoptotic CTCs to detect and profile the most relevant metastasis-initiating CTCs. Finally, it is crucial to be able to analyze the captured CTCs at the molecular level and to compare their characteristics to those of the primary tumor and overt metastases.

There is now strong interest in developing microdevices that can handle sample volumes at least ten times smaller than those required for current tests $(<1 \mathrm{ml}$ of blood versus 5 to $20 \mathrm{ml}$ ), thereby minimizing assay time and the use of expensive staining reagents. However, CTCs are very rare and the analysis of larger blood volumes $(\geq 20 \mathrm{ml})$ might be preferable, particularly in early-stage cancer patients with a small burden of CTCs. Thus, technologies that can handle larger blood volumes still deserve special attention.

The current CTC devices need to implement physical know-how and information on the biology of tumor cell dissemination, and intense clinical validation of these devices is required before their introduction into the management of cancer patients.

\section{Clinical relevance of circulating tumor cells Clinical utility of circulating tumor cells as a prognostic marker}

CTC detection is possible at both early and late stages of cancer development and might allow estimation of the risk of relapse and survival. Yields of these rare cells range from one identified cell up to several hundreds of cells per blood sample. It is still under debate whether the presence of one cell might be clinically relevant and what CTC count thresholds should be used in order to establish disease-free or overall survival. Most research groups apply a prognostic cut-off of five CTCs as established by Cristofanilli and colleagues in metastatic breast cancer patients $[15,16]$.

Yields of tumor cells separated from peripheral blood are low in metastatic breast cancer but are still sufficient for further analysis; in early stages of breast cancer, however, these counts are even lower and frequently do not exceed five CTCs per 7.5 to $10 \mathrm{ml}$ of blood [2]. Identification of CTCs at this stage of disease is still a challenge. Nevertheless, the finding of even a single CTC in a blood volume as small as $7.5 \mathrm{ml}$ was shown to associate with an increased risk for subsequent metastases [17,18], which suggests that CTCs might metastasize more efficiently than deduced from animal experiments [7].

Although most CTC studies are performed on subjects with metastatic breast cancer, CTC technologies might have the greatest impact on the treatment of patients without overt metastasis. CTC detection was proven to predict prognosis in clinically relevant subgroups of early-stage breast cancer patients $[4,19]$. The still ongoing German 'SUCCESS' trial, which has enrolled almost 1,500 lymph node-positive and high-risk lymph nodenegative but metastasis-free breast cancer patients before and after taxane-based adjuvant therapy, defined that at least one CTC was evident in $10 \%$ of the patients at the time of primary diagnosis before adjuvant therapy, and a significantly better prognosis was detected in the groups with persistently negative CTC status [20].

\section{Circulating tumor cells as predictor of response to therapy}

Predicting patients' responses to therapeutic regimens is probably one of the most exciting applications of CTC technology. Consequently, several studies have suggested that the presence of CTCs that have survived therapy might reflect a failure of systemic therapy [21,22]. Establishing that CTCs indicate progression during chemotherapy even 7 to 9 weeks before radiological imaging does so, Liu and colleagues [23] provided the first strong evidence that CTC tests might replace imperfect standard imaging procedures in the future.

Maintaining less than five CTCs or decreasing CTC counts during therapy is considered to be an indicator of good response to treatment. RT-PCR-based detection of cytokeratin (CK)19 mRNA-positive CTCs after adjuvant therapy in early breast cancer patients was reported to be an independent risk factor for resistant residual disease [24]. CTC counts in 115 non-metastatic breast cancer patients before and after primary systemic chemotherapy in a phase II trial (REMAGUS02) was an independent prognostic factor for shorter metastasis-free survival but did not correlate with pathologic complete response of the primary tumor to therapy $[17,25]$. In the 'GEPARQuattro' trial, which included 213 non-metastatic breast cancer patients, the prevalence of CTC-positive patients dropped from $22 \%$ before to $11 \%$ after neo-adjuvant therapy and again no associations were found with primary tumor response [26].

It has been suggested that CTC counts might depend on the form of treatment. For example, the humanized monoclonal antibody bevacizumab, which recognizes vascular endothelial growth factor A, combined with first-line chemotherapy modified the predictive value of CTCs during treatment of metastatic breast cancer patients, possibly due to impaired tumor-cell intravasation through blood vessel endothelium [27]. 
Table 2. Comparison of CTC and DTC detection in breast cancer

\begin{tabular}{|c|c|c|c|c|c|c|c|c|c|}
\hline \multirow[b]{2}{*}{ Detection method } & \multirow[b]{2}{*}{$\begin{array}{l}\text { Patient } \\
\text { status }\end{array}$} & \multirow[b]{2}{*}{ Remarks } & \multirow{2}{*}{$\begin{array}{c}\text { Total } \\
\text { number } \\
\text { of patients }\end{array}$} & \multicolumn{4}{|c|}{$\mathrm{n}(\%)$} & \multirow[b]{2}{*}{$\begin{array}{c}\text { Concordance } \\
(\%)\end{array}$} & \multirow[b]{2}{*}{ Reference } \\
\hline & & & & $\begin{array}{l}\text { CTC+, } \\
\text { DTC+ }\end{array}$ & $\begin{array}{l}\text { CTC+, } \\
\text { DTC- }\end{array}$ & $\begin{array}{l}\text { CTC-, } \\
\text { DTC+ }\end{array}$ & $\begin{array}{l}\text { CTC-, } \\
\text { DTC- }\end{array}$ & & \\
\hline Pan-CK staining & $\mathrm{M} 0$ and $\mathrm{M} 1$ & - & 114 & $26(22.8)$ & $2(1.7)$ & $41(35.9)$ & $45(39.4)$ & 62.3 & {$[35]$} \\
\hline Pan-CK staining & $\mathrm{M} 0$ and $\mathrm{M} 1$ & - & 53 & $3(5.6)$ & $2(3.7)$ & $6(11.3)$ & $42(79.2)$ & 84.9 & [21] \\
\hline RT-PCR & $\mathrm{M} 0$ and $\mathrm{M} 1$ & Detection of CK19 & 148 & $8(5.4)$ & $14(9.5)$ & $34(22.9)$ & $92(62.2)$ & 67.5 & [33] \\
\hline CK19 or mammaglobin & $\mathrm{M} 0$ and $\mathrm{M} 1$ & Detection of mammaglobin & 148 & $11(7.4)$ & $18(12.2)$ & $19(12.8)$ & $100(67.6)$ & 75.0 & [33] \\
\hline CK-staining & Mo & - & 341 & $8(2.3)$ & $26(7.6)$ & $40(11.7)$ & $267(78.3)$ & 80.6 & [29] \\
\hline Pan-CK staining & $\mathrm{M} 0$ and $\mathrm{M} 1$ & - & 39 & $12(30.8)$ & $3(7.6)$ & $12(30.8)$ & $12(30.8)$ & 61.5 & {$[34]$} \\
\hline \multirow[t]{2}{*}{ RT-PCR, CK19 } & MO & $\begin{array}{l}\text { Patients before } \\
\text { neo-adjuvant therapy }\end{array}$ & 165 & $88(53.3)$ & $3(1.8)$ & $7(4.2)$ & $67(40.6)$ & 93.9 & {$[31]$} \\
\hline & & $\begin{array}{l}\text { Patients after } \\
\text { neo-adjuvant therapy }\end{array}$ & 84 & $32(38.1)$ & $12(14.2)$ & $11(13.1)$ & $29(34.5)$ & 72.6 & {$[31]$} \\
\hline CellSearch $^{\circledast}$, RT-PCR & Mo & High-risk patients & 27 & $16(59.2)$ & $4(14.8)$ & $3(11.2)$ & $4(14.8)$ & 74.1 & {$[22]$} \\
\hline Pan-CK staining, CellSearch ${ }^{\oplus}$ & MO & - & 63 & $5(7.9)$ & $13(20.6)$ & $15(23.8)$ & $30(47.6)$ & 55.5 & [18] \\
\hline Avarage & & & & & & & & 72.8 & \\
\hline Minimum & & & & & & & & 55.5 & [18] \\
\hline Maximum & & & & & & & & 93.9 & [31] \\
\hline
\end{tabular}

Abbreviations: M0, no detected metastasis; M1, metastasis; n, number of patients; RT-PCR, reverse transcription polymerase chain reaction.

CTC-based identification of early progression might offer the possibility of an immediate change of therapy instead of waiting for classic clinical-radiological evidence of progressive disease. Ongoing studies aim to answer the question of whether individualization of treatment decisions can indeed be based on CTC levels (for example, Southwest Oncology Group randomized trial SWOG S0500 on metastatic breast cancer patients [28], German Breast Group GEPARQuattro trial on non-metastatic breast cancer patients [29], and SUCCESS trial on nonmetastatic breast cancer patients [30]). The first example of potential clinical benefit arising from a change in therapeutic regimen on the basis of CTC count is the case report on a metastatic breast cancer patient first treated with HER-2-targeting trastuzumab and subsequently with the dual epithelial growth factor receptor (EGFR) and HER-2 inhibitor lapatinib [31]. Indeed, the change in therapy resulted in the depletion of EGFRpositive CTCs and response of the primary tumor. Tumor progression was related to recurrence of CTCs that were both HER-2 and EGFR negative, suggesting therapyinduced selection of target-negative metastatic cells.

Relation between CTCs in blood and DTCs in bone marrow Though initial investigations have provided evidence that CTCs might be a promising prognostic marker, it is still unclear whether they provide the same clinical information as DTCs. To the best of our knowledge, comparative analyses of CTCs and DTCs have been performed in only a few studies.

The yield of CTCs was estimated to be lower than that of DTCs [32] but this depends on the techniques used for CTC/DTC detection. Some authors reported that it reached greater levels only in bone marrow-positive cases [21,33] and in high-risk patients [22]. CTCs and DTCs are detected in individual patients at the same time with variable concordance rates (Table 2). Differences observed in some studies might be explained to some extent by the different technologies used to detect CTCs and DTCs. Interestingly, higher overall discordance of CTC and DTC counts was found in patients after rather than before adjuvant therapy [34], which suggests differential sensitivity of DTCs and CTCs to chemotherapy. In this context, it might be noteworthy that DTCs may express a set of stress response proteins that may help them to survive chemotherapy [35].

Controversy also remains regarding the clinical relevance of CTCs versus DTCs. Some authors showed superior performance of DTCs in predicting overall survival in both non-metastatic and metastatic breast cancer patients $[32,36]$. In contrast, others reported that CTCs predict overall survival in metastatic patients, whereas DTCs do not [37]. Pierga and colleagues [38] reported that CTCs and DTCs have identical impact on overall survival of non-metastatic and metastatic patients but disease-free survival is predicted only by DTCs. 
Simultaneous detection of CTCs and DTCs was shown to be associated with an especially poor prognosis and increased incidence of disease-related deaths in nonmetastatic breast cancer patients [32,34].

Of note, it has recently been reported that counts of disseminating tumor cells vary not only between bone marrow and peripheral blood but probably depend also on the vascular compartment from which blood is being collected [39]. Substantially higher numbers of CTCs were counted in central veins than in peripheral veins. It might be speculated that the numbers of DTCs/CTCs might be site-specific because the microvascular system of different organs might have a variable potency for filtering CTCs/DTCs.

\section{Biology of circulating tumor cells}

Viability and proliferative activity of circulating tumor cells CTCs separated from peripheral blood of cancer patients seem to represent a heterogonous pool of tumor cells (Figure 2) with an average half-life of 1 to 2.4 hours [40]. CTCs found in peripheral blood might be apoptotic or viable but most currently applied assays do not discriminate this status. They also do not distinguish cycling and non-cycling CTCs. Both features, however, might significantly influence overall response to therapies.

To the best of our knowledge, the first test for detecting viable disseminating breast tumor cells was the EpiSpot, which detects them according to their secretion of CK19 and MUC-1 (Figure 2) [41]. More recently, the addition of the early apoptosis marker M30 to classic cytokeratin staining has enabled assessment of the ratio of viable to dead CTCs [42] (Figure 2).

Expression of the nuclear protein Ki-67, which is associated with cell proliferation, was reported to be absent or rare in CTCs of breast cancer patients $[21,43]$ (Figure 1), which implies that these cells might display the phenotype of non-cycling, so-called dormant cancer cells. These non-dividing cells might also not respond to some of the currently used chemotherapeutics, as indicated by the fact that a fraction of CTCs survives these therapies (see above).

\section{Expression of epithelial marker genes on circulating tumor cells}

Classic epithelial markers such as EpCAM or certain CKs are frequently not sufficient to detect the entire CTC population in blood [44]. It was reported that the CellSearch $^{\odot}$ method, based on the detection of EpCam antigen, does not recognize normal-like breast cancer cells, which in general demonstrate aggressive features [45]. Only a method using another marker, CD146 (also called MCAM or MUC18), enabled assessment of reliable numbers of CTCs in advanced normal-like breast cancer patients [46]. One explanation for why CTC isolation based on classic epithelial markers does not detect all tumor cells in peripheral blood is that single antibodies, sold as 'broad spectrum' or 'pan' CK antibodies, do not detect all CK proteins expressed in breast cancer cells [47]; thus, only appropriate cocktails of CK antibodies increase overall detection rates and reduce the risk of false-negative findings.

Recent work on EpCAM signaling [48] sheds new light on a probable altered phenotype of CTCs. Commercially available antibodies against this glycoprotein recognize only its extracellular domain, whereas EpCAM might be cleaved by proteases, which in turn leads to relocation of its intracellular domain into the cell nucleus. Interestingly, cells with ЕРCAM in their nuclei but not on the cellular membrane might be oncogenic in vivo [48]. It seems that expression and cleavage of EpCAM is associated with a temporary need for proliferation of tumor cells [48], which might be essentially reduced when tumor cells enter the bloodstream. Thus, it might be speculated that EpCAM-positive tumors also release cells that lose this molecule from the cellular membrane during extravasation and re-express it only in metastatic sites.

\section{Partial mesenchymal transition of circulating tumor cells}

Another reason that certain pools of CTCs might be missed during standard epithelial marker-based screening might be their altered phenotype resulting from EMT, currently dynamically investigated in terms of tumor aggressiveness. Epithelial tumor cells under specific external stimuli or with internal aberrations might transform into cells with a mesenchymal or semi-mesenchymal phenotype $[9,49]$. Expression of epithelial markers in such cells might be limited or weak, which might lead to false-negative results in CTC tests.

Cell lines derived from DTCs isolated from bone marrow of cancer patients indeed demonstrate signatures of EMT, such as low relative levels of epithelial CKs (CK7, CK8, CK17, CK18 and CK19) and increased expression of the mesenchymal intermediate filament vimentin [35]. Several groups investigated this phenomenon in peripheral blood of breast cancer patients using variable EMT-associated markers. Aktas and colleagues [50] observed at least one of the selected EMT markers (Twist 1, Akt2 or PI3Kalpha) in $62 \%$ of CTC-positive and $7 \%$ of CTC-negative cancer patients (Figure 2). In contrast, another research group using a set of EMT-initiating transcription factors (Twist, Snaill, Slug, Zeb1 and FoxC2; Figure 2) showed that overexpression of at least one of these factors was detected in only $15.4 \%$ of patients [51]. Raimondi and colleagues [52] reported the presence of two EMT markers, vimentin and fibronectin, in both CK-positive and -negative cells in the blood of $28 \%$ and $38 \%$ of patients, respectively. Similarly, 


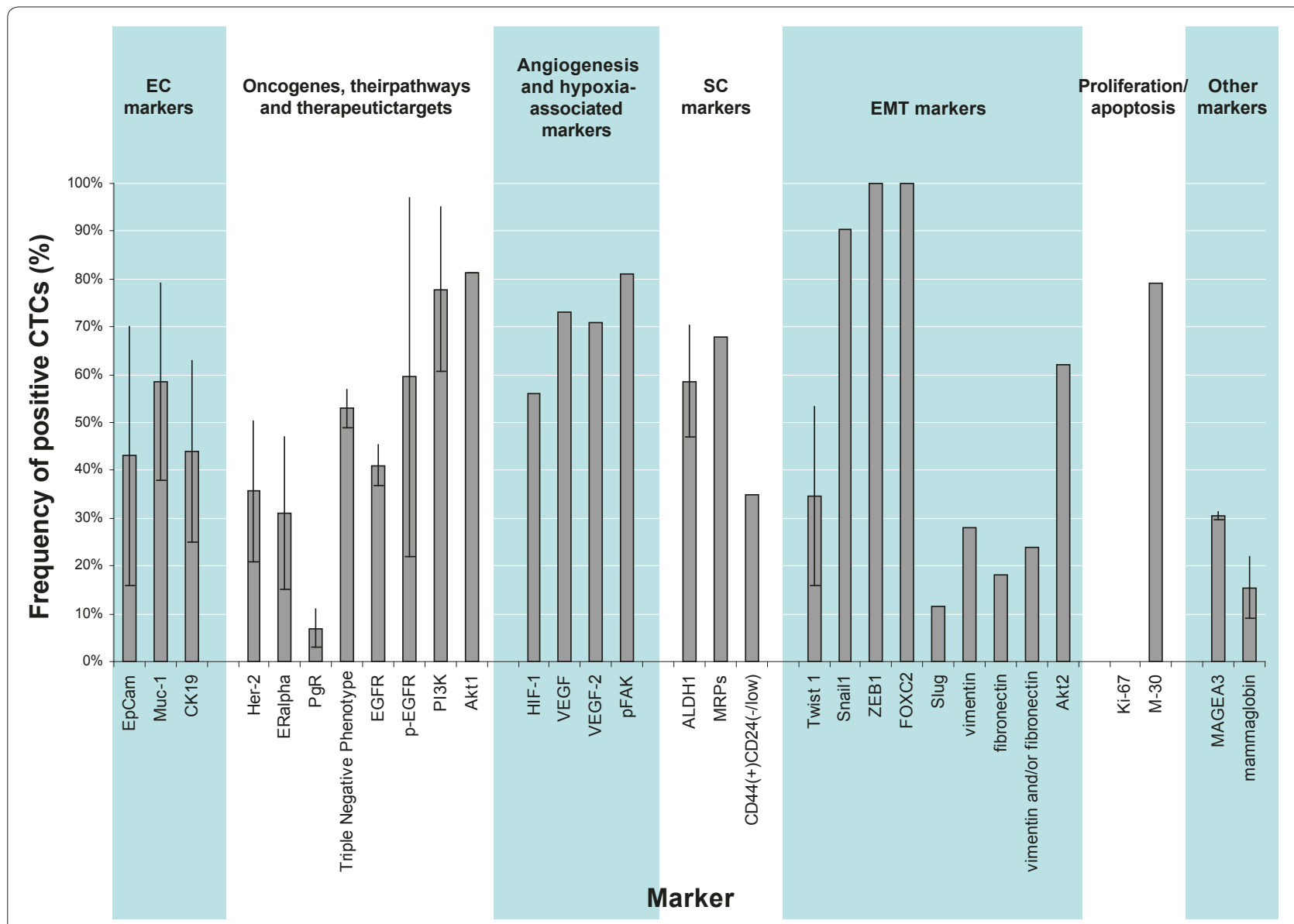

Figure 2. Frequency of molecular markers expressed in circulating tumor cells of breast cancer patients. The shown frequencies are based on data from the literature $[21,26,33,42-53,58,59,61-65,75,86-91]$ and they refer to the reported frequency (percentage of total number of circulating tumor cells (CTCS) detected in the particular report) of CTCs positive for the described marker. Markers for which there is more than one report are presented as the mean value and standard deviation of the available data in the literature. Abbreviations: ALDH1, aldehyde dehydrogenase 1; CK19, cytokeratin 19; EC, epithelial cell; EGFR, epithelial growth factor receptor; EMT, epithelial-mesenchymal transition; EpCAM, epithelial cell adhesion molecule; ERalpha, estrogen receptor alpha; Her-2, epithelial growth factor receptor type 2; HIF-1, hypoxia-inducible factor 1; MAGEA3, melanoma-associated antigen 3; MRP, multidrug resistant protein; Muc-1, mucin 1; p-EGFR, phosphorylated epithelial growth factor receptor; pFAK, phosphorylated focal adhesion kinase; PgR, progesterone receptor; PI3K, phosphatidylinositol 3-kinase; SC, stem cell; VEGF, vascular endothelial growth factor; ZEB1, zinc finger E-box-binding homeobox 1.

Gradilone and colleagues [53] found that fibronectin and/or vimentin were expressed more frequently in CKnegative than in CK-positive blood samples (EMT marker positivity in $55 \%$ versus $43 \%$ of samples, respectively; Figure 2). Both groups noted no expression of these proteins in blood of healthy donors. These published studies suggest that a pool of CTCs might have a semi-mesenchymal phenotype.

It is important to mention that patients receiving neoadjuvant therapy were more likely to exhibit overexpression of EMT markers than those who did not [51]. It was also demonstrated that EMT markers predicted worse prognosis more accurately than epithelial markers and even predicted it with statistical significance in patients with CK-negative blood samples [53]. These results imply that CTCs undergoing EMT might be a population of invasive cells resistant to neo-adjuvant therapy. They also demonstrate that EMT markers such as vimentin might complement epithelial markers for CTC detection, as indicated in prostate cancer [54]. However, vimentin is also expressed in a subpopulation of differentiated and/or activated monocytes [55], which can significantly hinder identification of CTCs in monocyte-rich fractions. Thus, it is apparent that EMTrelated markers that are specific for CTC detection are urgently needed.

Putative stem cell-like phenotype of circulating tumor cells EMT and stemness of tumor cells seem to be linked mechanistically $[10,56,57]$. Consequently, subpopulations 
of CTCs/DTCs may demonstrate a stem cell-like phenotype. Using different experimental set-ups, (over)expression rates of the putative stem cell marker ALDH1 in CTC-positive blood samples of breast cancer patients ranged from 46\% [52] to approximately 70\% [50] (Figure 2). As expected, ALDH1 was shown to be associated with EMT markers in these samples [50,52] and a higher stage of breast cancer [52]. Another group analyzed a total of 1,439 CTCs and determined that $35.2 \%$ of CTCs had the stem cell-like phenotype CD $44^{+} / \mathrm{CD} 24^{- \text {/low }}$ in 20 patients and $17.7 \%$ of CTCs with the stem cell-like phenotype $\mathrm{ALDH} 1^{\text {high }} / \mathrm{CD} 24^{- \text {llow }}$ in 7 patients [58] (Figure 2).

Considering the cancer stem cell model, self-renewal potency and resistance to variable chemotherapeutics make putative cancer stem cells particularly difficult to eradicate during medical intervention. In concordance, patients with ALDH1-positive CTCs more frequently did not respond to chemotherapy [50]. Recently, it was also demonstrated that CTCs in $86 \%$ of metastatic breast cancer patients expressed one or more different multidrug resistance-related proteins (MRP1, MRP4, MRP5 and MRP7), thought to be characteristic for putative cancer stem cells or at least tumor cells resistant to chemotherapy [59] (Figure 2). The patients with MRPpositive CTCs had significantly shorter time to progression [59].

\section{Altered geno-/phenotype of CTCs in comparison to the primary tumor}

Currently, molecular diagnostics of cancer patients focuses on primary tumors. However, the tumor mass at the primary site contains both invasive and non-invasive tumor cells, whereas for the assessment of risk of relapse or progression only invasive cells seem to be clinically relevant. CTCs represent a pool of tumor cells that have already spread in the system and are ready to establish themselves in a host organ; they are thus potentially dangerous from a clinical point of view. Dissimilarities between CTCs and their respective primary tumor might influence a patient's response to therapies selected only on the basis of the characteristics of the primary tumor $[60,61]$. Discrepancies in the phenotypes of CTCs and the primary tumor are indeed noted relatively frequently. HER-2-positive CTCs were demonstrated to occur in patients with HER-2-negative primary breast cancer and, conversely, HER-2-negative CTCs were observed in patients with HER-2-positive tumors [26,43,59,61-64]. Similar divergence was reported for EGFR [64], estrogen receptor alpha [59,65] and progesterone receptor [65]. This phenomenon might be explained by limitations of the used experimental set-ups and methods - for example, omitting clinically relevant but small clones of tumor cells within the primary tumor site displaying aberrant HER-2 gene/protein dosages. However, CTCs might undergo a strong selection during dissemination or systemic treatment and their genomic instability may lead to the generation of new tumor cell clones with phenotypic/genotypic features different to those of the primary tumor cells. In addition, CTCs might also be delivered to the blood circulation from secondary sites $[11,13]$ and therefore their genotype/phenotype might resemble cells from occult metastatic sites instead of those from the primary site. Taken together, direct assessment of CTCs for therapeutic targets or intracellular pathways interfering with the mode of action of the particular drug may provide valuable information in addition to current primary tumor analyses.

\section{Conclusions}

A 'liquid biopsy' that can determine CTC yields and characteristics in the blood of cancer patients has the potential to become one of the most promising tests in oncology, equivalent to the blood glucose measurement available for insulin treatment in diabetes patients [66]. The reported data are very encouraging, but multicentre studies including larger cohorts of patients, longer observation periods, more detailed molecular characterization of CTCs and more standardized procedures are still needed in order to estimate the clinical utility of CTCs as an independent biomarker. Future analyses should focus on the nature of CTCs and show whether changes in their counts and properties can predict patient response to specific therapies and thereby complement current diagnostic tests.

\section{Abbreviations}

CK, cytokeratin; CTC, circulating tumor cell; DTC, disseminated tumor cell; EGFR, epithelial growth factor receptor; EMT, epithelial-mesenchymal transition; EPCAM, epithelial cell adhesion molecule; RT-PCR, reverse transcription polymerase chain reaction.

\section{Competing interests}

KP has received research grants and speaker's honoria from Veridex. CAP has received honoraria from Veridex. NBK has no potential conflict of interest to declare.

\section{Authors' contributions}

All authors contributed to the writing of the manuscript.

\section{Acknowledgements}

This work was supported by grants from the Bundesministerium für Bildung und Forschung, the European Commission (DISMAL-project, contract no. LSHC-CT-2005-018911). The authors apologize to all research groups whose excellent work was not acknowledged in the current review due to space limitations.

\section{Author details}

'Department of Tumour Biology, University Medical Centre HamburgEppendorf, Martinistr. 52, 20246 Hamburg, Germany. ${ }^{2}$ University Medical Centre, Saint-Eloi Hospital, Institute of Research in Biotherapy, Laboratory of Rare Human Circulating Cells, 80 avenue Augustin Fliche, 34295 Montpellier Cedex 5, France. ${ }^{3}$ University Medical Centre, Laboratory of Cell and Hormonal Biology, Arnaud de Villeneuve Hospital, 37, avenue du Doyen Gaston Giraud, 34295 Montpellier Cedex 5, France. ${ }^{4}$ University Institute of Clinical Research UM1 - EA2415 - Epidemiology, Biostatistics and Public Health, 641 avenue du Doyen G. Giraud, 34093 Montpellier Cedex 5, France. 
Published: 1 November 2011

\section{References}

1. Pantel K, Brakenhoff RH, Brandt B: Detection, clinical relevance and specific biological properties of disseminating tumor cells. Nat Rev Cancer 2008, 8:329-340.

2. Pantel $\mathrm{K}$, Alix-Panabières $\mathrm{C}$, Riethdorf $\mathrm{S}$ : Cancer micrometastases. Nat Rev Clin Oncol 2009, 6:339-351.

3. Janni W, Vogl FD, Wiedswang G, Synnestvedt M, Fehm T, Jückstock J, Borgen E, Rack B, Braun S, Sommer H, Solomayer E, Pantel K, Nesland J, Friese K, Naume B: Persistence of disseminated tumor cells in the bone marrow of breast cancer patients predicts increased risk for relapse - a European pooled analysis. Clin Cancer Res 2011, 17:2967-2976.

4. Pantel K, Brakenhoff RH: Dissecting the metastatic cascade. Nat Rev Cancer 2004, 4:448-456.

5. Pantel $\mathrm{K}$, Alix-Panabières $\mathrm{C}$ : Circulating tumour cells in cancer patients: challenges and perspectives. Trends Mol Med 2010, 16:398-406.

6. Wicha MS, Hayes DF: Circulating tumor cells: not all detected cells are bad and not all bad cells are detected. J Clin Oncol 2011, 29:1508-1511.

7. Chambers AF, Groom AC, MacDonald IC: Dissemination and growth of cancer cells in metastatic sites. Nat Rev Cancer 2002, 2:563-572.

8. Bonnomet A, Brysse A, Tachsidis A, Waltham M, Thompson EW, Polette M, Gilles C: Epithelial-to-mesenchymal transitions and circulating tumor cells. J Mammary Gland Biol Neoplasia 2010, 15:261-273.

9. Chaffer $C L$, Weinberg RA: A perspective on cancer cell metastasis. Science 2011, 331:1559-1564.

10. Hanahan D, Weinberg RA: Hallmarks of cancer: the next generation. Cell 2011, 144:646-674

11. Goss PE, Chambers AF: Does tumour dormancy offer a therapeutic target? Nat Rev Cancer 2010, 10:871-877.

12. Kim MY, Oskarsson T, Acharyya S, Nguyen DX, Zhang XH, Norton L, Massaqué J: Tumor self-seeding by circulating cancer cells. Cell 2009, 139:1315-1326.

13. Comen E, Norton L, Massagué J: Clinical implications of cancer self-seeding. Nat Rev Clin Oncol 2011, 8:369-377.

14. Klein CA: Parallel progression of primary tumours and metastases. Nat Rev Cancer 2009, 9:302-312.

15. Cristofanilli M, Budd GT, Ellis MJ, Stopeck A, Matera J, Miller MC, Reuben JM, Doyle GV, Allard WJ, Terstappen LW, Hayes DF: Circulating tumor cells, disease progression, and survival in metastatic breast cancer. N Eng/ J Med 2004, 351:781-791.

16. Cristofanilli M, Hayes DF, Budd GT, Ellis MJ, Stopeck A, Reuben JM, Doyle GV, Matera J, Allard WJ, Miller MC, Fritsche HA, Hortobagyi GN, Terstappen LW: Circulating tumor cells: a novel prognostic factor for newly diagnosed metastatic breast cancer. J Clin Oncol 2005, 23:1420-1430.

17. Bidard FC, Mathiot C, Delaloge S, Brain E, Giachetti S, de Cremoux P, Marty M, Pierga JY: Single circulating tumor cell detection and overall survival in nonmetastatic breast cancer. Ann Oncol 2010, 21:729-733.

18. Krishnamurthy S, Cristofanilli M, Singh B, Reuben J, Gao H, Cohen EN, Andreopoulou E, Hall CS, Lodhi A, Jackson S, Lucci A: Detection of minimal residual disease in blood and bone marrow in early stage breast cancer. Cancer 2010, 116:3330-3337.

19. Cristofanilli M, Braun S: Circulating tumor cells revisited. JAMA 2010, 303:1092-1093.

20. Rack BK, Schindlbeck C, Andergassen U, Schneeweiss A, Zwingers T, Lichtenegger W, Beckmann M, Sommer HL, Pantel K, Janni W: for the SUCCESS Study Group: Use of circulating tumor cells (CTC) in peripheral blood of breast cancer patients before and after adjuvant chemotherapy to predict risk for relapse: The SUCCESS trial [abstract]. J Clin Oncol 2010, 28:15s

21. Müller V, Stahmann N, Riethdorf S, Rau T, Zabel T, Goetz A, Jänicke F, Pantel K: Circulating tumor cells in breast cancer: correlation to bone marrow micrometastases, heterogeneous response to systemic therapy and low proliferative activity. Clin Cancer Res 2005, 11:3678-3685.

22. Slade MJ, Payne R, Riethdorf S, Ward B, Zaidi SA, Stebbing J, Palmieri C, Sinnett HD, Kulinskaya E, Pitfield T, McCormack RT, Pantel K, Coombes RC Comparison of bone marrow, disseminated tumour cells and bloodcirculating tumour cells in breast cancer patients after primary treatment. BrJ Cancer 2009, 100:160-166

23. Liu MC, Shields PG, Warren RD, Cohen P, Wilkinson M, Ottaviano YL, Rao SB, Eng-Wong J, Seillier-Moiseiwitsch F, Noone AM, Isaacs C: Circulating tumor cells: a useful predictor of treatment efficacy in metastatic breast cancer.
J Clin Oncol 2009, 27:5153-5159.

24. Xenidis N, Ignatiadis M, Apostolaki S, Perraki M, Kalbakis K, Agelaki S, Stathopoulos EN, Chlouverakis G, Lianidou E, Kakolyris S, Georgoulias V, Mavroudis D: Cytokeratin-19 mRNA-positive circulating tumor cells after adjuvant chemotherapy in patients with early breast cancer. J Clin Oncol 2009, 27:2177-2184.

25. Pierga JY, Bidard FC, Mathiot C, Brain E, Delaloge S, Giachetti S, de Cremoux P, Salmon R, Vincent-Salomon A, Marty M: Circulating tumor cell detection predicts early metastatic relapse after neoadjuvant chemotherapy in large operable and locally advanced breast cancer in a phase II randomized trial. Clin Cancer Res 2008, 14:7004-7010.

26. Riethdorf S, Müller V, Zhang L, Rau T, Loibl S, Komor M, Roller M, Huober J, Fehm T, Schrader I, Hilfrich J, Holms F, Tesch H, Eidtmann H, Untch M, von Minckwitz G, Pantel K: Detection and HER2 expression of circulating tumor cells: prospective monitoring in breast cancer patients treated in the neoadjuvant GeparQuattro trial. Clin Cancer Res 2010, 16:2634-2645.

27. Bidard FC, Mathiot C, Degeorges A, Etienne-Grimaldi MC, Delva R, Pivot X, Veyret C, Bergougnoux L, de Cremoux P, Milano G, Pierga JY: Clinical value of circulating endothelial cells and circulating tumor cells in metastatic breast cancer patients treated first line with bevacizumab and chemotherapy. Ann Oncol 2010, 21:1765-1771.

28. SWOG S0500 [http://www.cancer.gov/clinicaltrials/search/view? cdrid= 504319\&version=healthprofessional]

29. GEPARQuattro trial [http://www.germanbreastgroup.de/studien/ neoadjuvant/geparquattro-/english-summaryhtml?lang=de_DE.UTF-8\%2C+de_CH.U]

30. SUCCESS [http://www.success-studie.de/]

31. Liu Z, Fusi A, Schmittel A, Tinhofer I, Schneider A, Keilholz U: Eradication of EGFR-positive circulating tumor cells and objective tumor response with lapatinib and capecitabine. Cancer Biol Ther 2010, 10:860-864.

32. Wiedswang G, Borgen E, Schirmer C, Kåresen R, Kvalheim G, Nesland JM, Naume B: Comparison of the clinical significance of occult tumor cells in blood and bone marrow in breast cancer. Int J Cancer 2006, 118:2013-2019.

33. Banys M, Krawczyk N, Becker S, Jakubowska J, Staebler A, Wallwiener D, Fehm $T$, Rothmund R. The influence of removal of primary tumor on incidence and phenotype of circulating tumor cells in primary breast cancer. Breast Cancer Res Treat 2011, in press.

34. Daskalaki A, Agelaki S, Perraki M, Apostolaki S, Xenidis N, Stathopoulos E, Kontopodis E, Hatzidaki D, Mavroudis D, Georgoulias V: Detection of cytokeratin-19 mRNA-positive cells in the peripheral blood and bone marrow of patients with operable breast cancer. Br J Cancer 2009, 101:589-597.

35. Bartkowiak K, Wieczorek M, Buck F, Harder S, Moldenhauer J, Effenberger KE, Pantel K, Pater-Katalanic J, Brandt BH: Two-dimensional differential gel electrophoresis of a cell line derived from a breast cancer micrometastasis revealed a stem/progenitor cell protein profile. J Proteome Res 2009, 9:3158-3168.

36. Benoy IH, Elst H, Philips M, Wuyts H, Van Dam P, Scharpé S, Van MarckE, Vermeulen PB, Dirix LY: Real-time RT-PCR detection of disseminated tumour cells in bone marrow has superior prognostic significance in comparison with circulating tumour cells in patients with breast cancer. $\mathrm{Br}$ $J$ Cancer 2006, 94:672-680

37. Bidard FC, Vincent-Salomon A, Sigal-Zafrani B, Diéras V, Mathiot C, Mignot L, Thiery JP, Sastre-Garau X, Pierga JY: Prognosis of women with stage IV breast cancer depends on detection of circulating tumor cells rather than disseminated tumor cells. Ann Oncol 2008, 19:496-500.

38. Pierga JY, Bonneton C, Vincent-Salomon A, de Cremoux P, Nos C, Blin N, Pouillart P, Thiery JP, Magdelénat $\mathrm{H}$ : Clinical significance of immunocytochemical detection of tumor cells using digital microscopy in peripheral blood and bone marrow of breast cancer patients. Clin Cancer Res 2004, 10:1392-1400

39. Peeters DJ, Van den Eynden GG, van Dam PJ, Prové A, Benoy IH, van Dam PA Vermeulen PB, Pauwels P, Peeters M, Van Laere SJ, Dirix LY: Circulating tumour cells in the central and the peripheral venous compartment in patients with metastatic breast cancer. Br J Cancer 2011, 104:1472-1477.

40. Meng S, Tripathy D, Frenkel EP, Shete S, Naftalis EZ, Huth JF, Beitsch PD, Leitch M, Hoover S, Euhus D, Haley B, Morrison L, Fleming TP, Herlyn D, Terstappen LW, Fehm T, Tucker TF, Lane N, Wang J, Uhr JW: Circulating tumor cells in patients with breast cancer dormancy. Clin Cancer Res 2004, 10:8152-8162.

41. Alix-Panabières C, Vendrell JP, Slijper M, Pellé O, Barbotte E, Mercier G, Jacot W, Fabbro M, Pantel K: Full-length cytokeratin-19 is released by human tumor 
cells: a potential role in metastatic progression of breast cancer. Breast Cancer Res 2009, 11:R39.

42. Rossi E, Basso U, Celadin R, Zilio F, Pucciarelli S, Aieta M, Barile C, Sava T, Bonciarelli G, Tumolo S, Ghiotto C, Magro C, Jirillo A, Indraccolo S, Amadori A, Zamarchi R: M30 neoepitope expression in epithelial cancer: quantification of apoptosis in circulating tumor cells by CellSearch analysis. Clin Cancer Res 2010, 16:5233-5243.

43. Flores LM, Kindelberger DW, Ligon AH, Capelletti M, Fiorentino M, Loda M, Cibas ES, Jänne PA, Krop IE: Improving the yield of circulating tumour cells facilitates molecular characterisation and recognition of discordant HER2 amplification in breast cancer. Br J Cancer 2010, 102:1495-1502.

44. Königsberg R, Obermayr E, Bises G, Pfeiler G, Gneist M, Wrba F, De Santis M, Zeillinger R, Hudec M, Dittrich C: Detection of EpCAM positive and negative circulating tumor cells in metastatic breast cancer patients. Acta Oncol 2011, 50:700-710.

45. Sieuwerts AM, Kraan J, Bolt J, van der Spoel P, Elstrodt F, Schutte M, Martens JW, Gratama JW, Sleijfer S, Foekens JA: Anti-epithelial cell adhesion molecule antibodies and the detection of circulating normal-like breast tumor cells. J Natl Cancer Inst 2009, 101:61-66.

46. Mostert B, Kraan J, Bolt-de Vries J, van der Spoel P, Sieuwerts AM, Schutte M, Timmermans AM, Foekens R, Martens JW, Gratama JW, Foekens JA, Sleijfer S: Detection of circulating tumor cells in breast cancer may improve through enrichment with anti-CD146. Breast Cancer Res Treat 2011, 127:33-41.

47. Effenberger KE, Borgen E, Eulenburg CZ, Bartkowiak K, Grosser A, Synnestvedt M, Kaaresen R, Brandt B, Nesland JM, Pantel K, Naume B: Detection and clinical relevance of early disseminated breast cancer cells depend on their cytokeratin expression pattern. Breast Cancer Res Treat 2011, 125:729-738.

48. Maetzel D, Denzel S, Mack B, Canis M, Went P, Benk M, Kieu C, Papior P, Baeuerle PA, Munz M, Gires O: Nuclear signalling by tumour-associated antigen EpCAM. Nat Cell Biol 2009, 11:162-171.

49. Polyak K, Weinberg RA: Transitions between epithelial and mesenchymal states: acquisition of malignant and stem cell traits. Nat Rev Cancer 2009, 9:265-273.

50. Aktas B, Tewes M, Fehm T, Hauch S, Kimmig R, Kasimir-Bauer S: Stem cell and epithelial-mesenchymal transition markers are frequently overexpressed in circulating tumor cells of metastatic breast cancer patients. Breast Cancer Res 2009, 11:R46.

51. Mego M, Mani SA, Lee BN, Li C, Evans KW, Cohen EN, Gao H, Jackson SA, Giordano A, Hortobagyi GN, Cristofanilli M, Lucci A, Reuben JM: Expression of epithelial-mesenchymal transition-inducing transcription factors in primary breast cancer: The effect of neoadjuvant therapy. Int J Cancer 2011, in press.

52. Raimondi C, Gradilone A, Naso G, Vincenzi B, Petracca A, Nicolazzo C, Palazzo A, Saltarelli R, Spremberg F, Cortesi E, Gazzaniga P: Epithelial-mesenchymal transition and stemness features in circulating tumor cells from breast cancer patients. Breast Cancer Res Treat 2011, in press.

53. Gradilone A, Raimondi C, Nicolazzo C, Petracca A, Gandini O, Vincenzi B, Naso G, Aglianò AM, Cortesi E, Gazzaniga P: Circulating tumor cells lacking cytokeratin in breast cancer: the importance of being mesenchymal. J Cell Mol Med 2011, 15:1066-1070

54. Bednarz N, Eltze E, Semjonow A, Rink M, Andreas A, Mulder L, Hannemann J, Fisch M, Pantel K, Weier U-HG, Bielawski KP, Brandt B: BRCA1 loss pre-existing in small subpopulations of prostate cancer is associated with advanced disease and metastatic spread to lymph nodes and peripheral blood. Clin Cancer Res 2010, 16:3340-3348.

55. Mor-Vaknin N, Punturieri A, Sitwala K, Markovitz DM: Vimentin is secreted by activated macrophages. Nat Cell Biol 2003, 5:59-63.

56. May CD, Sphyris N, Evans KW, Werden SJ, Guo W, Mani SA: Epithelialmesenchymal transition and cancer stem cells: a dangerously dynamic duo in breast cancer progression. Breast Cancer Res 2011, 13:202.

57. Mani SA, Guo W, Liao MJ, Eaton EN, Ayyanan A, Zhou AY, Brooks M, Reinhard F, Zhang CC, Shipitsin M, Campbell LL, Polyak K, Brisken C, Yang J, Weinberg RA: The epithelial-mesenchymal transition generates cells with properties of stem cells. Cell 2008, 133:704-715.

58. Theodoropoulos PA, Polioudaki H, Agelaki S, Kallergi G, Saridaki Z, Mavroudis D, Georgoulias V: Circulating tumor cells with a putative stem cell phenotype in peripheral blood of patients with breast cancer. Cancer Lett 2010, 288:99-106.

59. Gradilone A, Naso G, Raimondi C, Cortesi E, Gandini O, Vincenti B, Saltarelli R, Chiapparono E, Spremberg F, Cristofanilli M, Frati L, Agliano AM, Gazzaniga P:
Circulating tumor cells (CTCs) in metastatic breast cancer (MBC): prognosis, drug resistance and phenotypic characterization. Ann Oncol 2011, 22:86-92.

60. Pestrin M, Bessi S, Galardi F, Truglia M, Biggeri A, Biagioni C, Cappadona S, Biganzoli L, Giannini A, Di Leo A: Correlation of HER2 status between primary tumors and corresponding circulating tumor cells in advanced breast cancer patients. Breast Cancer Res Treat 2009, 118:523-530.

61. Munzone E, Nolé F, Goldhirsch A, Botteri E, Esposito A, Zorzino L, Curigliano G, Minchella I, Adamoli L, Cassatella MC, Casadio C, Sandri MT: Changes of HER2 status in circulating tumor cells compared with the primary tumor during treatment for advanced breast cancer. Clin Breast Cancer 2010, 10:392-397.

62. Wülfing P, Borchard J, Buerger H, Heidl S, Zänker KS, Kiesel L, Brandt B: HER2positive circulating tumor cells indicate poor clinical outcome in stage I to III breast cancer patients. Clin Cancer Res 2006, 12:1715-1720.

63. Fehm T, Müller V, Aktas B, Janni W, Schneeweiss A, Stickeler E, Lattrich C, Löhberg CR, Solomayer E, Rack B, Riethdorf S, Klein C, Schindlbeck C, Brocker K, Kasimir-Bauer S, Wallwiener D, Pantel K: HER2 status of circulating tumor cells in patients with metastatic breast cancer: a prospective, multicenter trial. Breast Cancer Res Treat 2010, 124:403-412.

64. Kallergi G, Agelaki S, Kalykaki A, Stournaras C, Mavroudis D, Georgoulias V: Phosphorylated EGFR and PI3K/Akt signaling kinases are expressed in circulating tumor cells of breast cancer patients. Breast Cancer Res 2008, 10:R80.

65. Aktas B, Müller V, Tewes M, Zeitz J, Kasimir-Bauer S, Loehberg CR, Rack B, Schneeweiss A, Fehm T: Comparison of estrogen and progesterone receptor status of circulating tumor cells and the primary tumor in metastatic breast cancer patients. Gynecol Oncol 2011, 122:356-360.

66. Alix-Panabières $C$, Riethdorf $S$, Pantel $K$ : Circulating tumor cells and bone marrow micrometastasis. Clin Cancer Res 2008, 14:5013-5021.

67. Nagrath S, Sequist LV, Maheswaran S, Bell DW, Irimia D, Ulkus L, Smith MR, Kwak EL, Digumarthy S, Muzikansky A, Ryan P, Balis UJ, Tompkins RG, Haber DA, Toner M: Isolation of rare circulating tumour cells in cancer patients by microchip technology. Nature 2007, 450:1235-1239.

68. Maheswaran S, Sequist LV, Nagrath S, Ulkus L, Brannigan B, Collura CV, Inserra E, Diederichs S, lafrate AJ, Bell DW, Digumarthy S, Muzikansky A, Irimia D, Settleman J, Tompkins RG, Lynch TJ, Toner M, Haber DA: Detection of mutations in EGFR in circulating lung-cancer cells. N Engl J Med 2008 359:366-377.

69. Stott SL, Hsu CH, Tsukrov DI, Yu M, Miyamoto DT, Waltman BA, Rothenberg SM, Shah AM, Smas ME, Korir GK, Floyd FP Jr, Gilman AJ, Lord JB, Winokur D, Springer S, Irimia D, Nagrath S, Sequist LV, Lee RJ, Isselbacher KJ, Maheswaran $\mathrm{S}$, Haber DA, Toner M: Isolation of circulating tumor cells using a microvortex-generating herringbone-chip. Proc Natl Acad Sci U S A 2010, 107:18392-18397.

70. Stott SL, Lee RJ, Nagrath S, Yu M, Miyamoto DT, Ulkus L, Inserra EJ, UIman M, Springer S, Nakamura Z, Moore AL, Tsukrov DI, Kempner ME, Dahl DM, Wu CL, lafrate AJ, Smith MR, Tompkins RG, Sequist LV, Toner M, Haber DA, Maheswaran S: Isolation and characterization of circulating tumor cells from patients with localized and metastatic prostate cancer. Sci Trans/ Med 2010, 2:25ra23

71. Saliba AE, Saias L, Psychari E, Minc N, Simon D, Bidard FC, Mathiot C, Pierga JY, Fraisier V, Salamero J, Saada V, Farace F, Vielh P, Malaquin L, Viovy JL: Microfluidic sorting and multimodal typing of cancer cells in selfassembled magnetic arrays. Proc Natl Acad Sci U S A 2010, 107:14524-14529.

72. Talasaz AH, Powell AA, Huber DE, Berbee JG, Roh KH, Yu W, Xiao W, Davis MM, Pease RF, Mindrinos MN, Jeffrey SS, Davis RW: Isolating highly enriched populations of circulating epithelial cells and other rare cells from blood using a magnetic sweeper device. Proc Natl Acad Sci U S A 2009, 106:3970-3975.

73. Rolle A, Günzel R, Pachmann U, Willen B, Höffken K, Pachmann K: Increase in number of circulating disseminated epithelial cells after surgery for nonsmall cell lung cancer monitored by MAINTRAC(R) is a predictor for relapse: A preliminary report. World J Surg Oncol 2005, 3:18.

74. Ntouroupi TG, Ashraf SQ, McGregor SB, Turney BW, Seppo A, Kim Y, Wang X, Kilpatrick MW, Tsipouras P, Tafas T, Bodmer WF: Detection of circulating tumour cells in peripheral blood with an automated scanning fluorescence microscope. Br J Cancer 2008, 99:789-795.

75. Deng G, Herrler M, Burgess D, Manna E, Krag D, Burke JF: Enrichment with anti-cytokeratin alone or combined with anti-EpCAM antibodies significantly increases the sensitivity for circulating tumor cell detection in metastatic breast cancer patients. Breast Cancer Res 2008, 10:R69. 
76. Andreopoulou E, Yang LY, Rangel KM, Reuben JM, Hsu L, Krishnamurthy S, Valero V, Fritsche HA, Cristofanilli M: Comparison of assay methods for detection of circulating tumor cells (CTCs) in metastatic breast cancer (MBC): AdnaGen AdnaTest BreastCancer Select/Detect ${ }^{\text {TM }}$ versus Veridex CellSearch ${ }^{\text {TM }}$ system. Int J Cancer 2011, in press.

77. Alix-Panabières C, Vendrell JP, Pellé O, Rebillard X, Riethdorf S, Müller V, Fabbro $\mathrm{M}$, Pantel K: Detection and characterization of putative metastatic precursor cells in cancer patients. Clin Chem 2007, 53:537-539.

78. Lu J, Fan T, Zhao Q, Zeng W, Zaslavsky E, Chen JJ, Frohman MA, Golightly MG, Madajewicz S, Chen WT: Isolation of circulating epithelial and tumor progenitor cells with an invasive phenotype from breast cancer patients. Int J Cancer 2010, 126:669-683.

79. Vona G, Sabile A, Louha M, Sitruk V, Romana S, Schütze K, Capron F, Franco D, Pazzagli M, Vekemans M, Lacour B, Bréchot C, Paterlini-Bréchot P: Isolation by size of epithelial tumor cells : a new method for the immunomorphological and molecular characterization of circulatingtumor cells. Am J Pathol 2000, 156:57-63.

80. Pinzani P, Salvadori B, Simi L, Bianchi S, Distante V, Cataliotti L, Pazzagli M, Orlando C: Isolation by size of epithelial tumor cells in peripheral blood of patients with breast cancer: correlation with real-time reverse transcriptase-polymerase chain reaction results and feasibility of molecular analysis by laser microdissection. Hum Pathol 2006, 37:711-718.

81. Hofman VJ, llie MI, Bonnetaud C, Selva E, Long E, Molina T, Vignaud JM, Fléjou JF, Lantuejoul S, Piaton E, Butori C, Mourad N, Poudenx M, Bahadoran P, Sibon S, Guevara N, Santini J, Vénissac N, Mouroux J, Vielh P, Hofman PM: Cytopathologic detection of circulating tumor cells using the isolation by size of epithelial tumor cell method: promises and pitfalls. Am J Clin Pathol 2011, 135:146-156

82. Krivacic RT, Ladanyi A, Curry DN, Hsieh HB, Kuhn P, Bergsrud DE, Kepros JF, Barbera T, Ho MY, Chen LB, Lerner RA, Bruce RH: A rare-cell detector for cancer. Proc Natl Acad Sci U S A 2004, 101:10501-10504.

83. Somlo G, Lau SK, Frankel P, Hsieh HB, Liu X, Yang L, Krivacic R, Bruce RH: Multiple biomarker expression on circulating tumor cells in comparison to tumor tissues from primary and metastatic sites in patients with locally advanced/inflammatory, and stage IV breast cancer, using a novel detection technology. Breast Cancer Res Treat 2011, in press.

84. Gascoyne PR, Noshari J, Anderson TJ, Becker FF: Isolation of rare cells from cell mixtures by dielectrophoresis. Electrophoresis 2009, 30:1388-1398.
85. Tan SJ, Lakshmi RL, Chen P, Lim WT, Yobas L, Lim CT: Versatile label free biochip for the detection of circulating tumor cells from peripheral blood in cancer patients. Biosens Bioelectron 2010, 26:1701-1705.

86. Ignatiadis M, Kallergi G, Ntoulia M, Perraki M, Apostolaki S, Kafousi M, Chlouverakis G, Stathopoulos E, Lianidou E, Georgoulias V, Mavroudis D: Prognostic value of the molecular detection of circulating tumor cells using a multimarker reverse transcription-PCR assay for cytokeratin 19 mammaglobin A, and HER2 in early breast cancer. Clin Cancer Res 2008, 14:2593-2600.

87. Ignatiadis M, Xenidis N, Perraki M, Apostolaki S, Politaki E, Kafousi M, Stathopoulos EN, Stathopoulou A, Lianidou E, Chlouverakis G, Sotiriou C, Georgoulias V, Mavroudis D: Different prognostic value of cytokeratin-19 mRNA positive circulating tumor cells according to estrogen receptor and HER2 status in early-stage breast cancer. J Clin Oncol 2007, 25:5194-5202.

88. Kallergi G, Markomanolaki H, Giannoukaraki V, Papadaki MA, Strati A, Lianidou ES, Georgoulias V, Mavroudis D, Agelaki S: Hypoxia-inducible factor-1alpha and vascular endothelial growth factor expression in circulating tumor cells of breast cancer patients. Breast Cancer Res 2009, 11:R84.

89. Markou A, Strati A, Malamos N, Georgoulias V, Lianidou ES: Molecular characterization of circulating tumor cells in breast cancer by a liquid bead array hybridization assay. Clin Chem 2011, 57:421-430.

90. Meng S, Tripathy D, Shete S, Ashfaq R, Saboorian H, Haley B, Frenkel E, Euhus D, Leitch M, Osborne C, Clifford E, Perkins S, Beitsch P, Khan A, Morrison L, Herlyn D, Terstappen LW, Lane N, Wang J, Uhr J: uPAR and HER-2 gene status in individual breast cancer cells from blood and tissues. Proc Natl Acad Sci US A 2006, 103:17361-17365.

91. Fehm T, Hoffmann O, Aktas B, Becker S, Solomayer EF, Wallwiener D, Kimmig $R$, Kasimir-Bauer S: Detection and characterization of circulating tumor cells in blood of primary breast cancer patients by RT-PCR and comparison to status of bone marrow disseminated cells. Breast Cancer Res 2009,11:R59.

doi:10.1186/bcr2940

Cite this article as: Bednarz-Knoll N, et al:. Clinical relevance and biology of circulating tumor cells. Breast Cancer Research 2011, 13:228. 